\title{
Diabetes control could through platelet-to-lymphocyte ratio in hemograms
}

\author{
Durcin Atak ${ }^{1}$ \\ (iD) Gulali Aktas ${ }^{1}$ \\ (iD)Tuba T. Duman' \\ (iD) Edip Erkus ${ }^{1}$ \\ (iD). Zahid Kocak ${ }^{1}$ \\ (iD) Haluk Savli
}

1. Abant Izzet Baysal University Hospital, Department of Internal Medicine, Bolu, Turkey

http://dx.doi.org/10.1590/1806-9282.65.1.38

\section{SUMMARY}

OBJECTIVE: Association between type 2 diabetes mellitus and inflammation is well-established. We aimed to study platelet-to-lymphocyte ratio $(P L R)$, a novel inflammatory index derived from hemogram, in diabetic patients in comparison to those in healthy volunteers. METHODS: Medical data of type 2 diabetics that showed up in general outpatient medical clinics of our institution between February 2017 and August 2017 were recorded and analyzed.

RESULTS: Median PLR of type 2 diabetic patients was significantly higher than the PLR of healthy controls ( $p=0.001)$. Moreover, $P L R$ was significantly and positively correlated with HbA1c $(p<0.001, r=0.58)$, fasting plasma glucose $(p<0.001, r=0.49)$, and $c$-reactive protein $(p=0.003, r=0.30)$ levels. Type 2 diabetic subjects with proteinuria had significantly higher PLR levels than that of diabetic subjects without proteinuria.

CONCLUSION: As an inexpensive and easy to use index, PLR may be useful in predicting the development and control levels of type 2 diabetes mellitus. However, its correlation with $\mathrm{HbATc}$ needs to be validated by larger prospective studies.

KEYWORDS: Diabetes mellitus, type 2. Inflammation. Glycated hemoglobin A. Lymphocyte count. Platelet count.

\section{INTRODUCTION}

Type 2 diabetes mellitus (DM) has reached nearly epidemic levels worldwide. Clinical and experimental studies focus on a better understanding of the pathophysiology in order to develop more effective treatment options. Type $2 \mathrm{DM}$ is associated with lowgrade inflammation. Moreover, diabetes control levels, such as glycated hemoglobin (HbA1c) levels, can be predicted by circulating inflammatory biomarkers. It is reported in the literature that inflammatory indexes in serum are correlated with HbA1c levels in type 2 diabetic subjects. ${ }^{1}$

Hemogram parameters have attracted great attention from researchers as novel inflammatory parameters. One of them is the platelet-to-lymphocyte ratio, which is derivated through the simple division of the platelet count by the lymphocyte count in a hemogram test. Platelet-to-lymphocyte ratio (PLR) has been proposed as a novel inflammatory marker for 
several cardiac, rheumatologic, and neoplastic conditions. ${ }^{2-4}$ Therefore, we hypothesized that PLR could be associated with type $2 \mathrm{DM}$ as well.

The aim of the present study was to compare PLR levels of type 2 diabetic patients to those of healthy controls. We also aimed to research the possible correlation between HbA1c and PLR in patients with type $2 \mathrm{DM}$.

\section{METHODS}

After the institutional board approved the study, we retrospectively analyzed the data of patients with type 2 DM whose admissions to our hospital occurred between February and August 2017. Control subjects enrolled were healthy subjects that visited the clinic for routine check-ups. Age, gender, height, weight, waist circumference, systolic blood pressure (SBP), diastolic blood pressure (DBP), diabetes complications (if any), comorbidities, use of anti-diabetic drugs, HbA1c level, hemogram parameters - such as white blood cell count (WBC), lymphocyte count (lym), hemoglobin (Hb), hematocrit (Htc), and platelet count (PLT) - were recorded. Fasting glucose, total cholesterol, LDL cholesterol, HDL cholesterol, triglyceride, c- reactive protein (CRP), uric acid levels were also obtained from a biochemical laboratory database of test results. The body mass index (BMI) was simply calculated by dividing the weight in kilograms by the squared height in meters. PLR was measured as a derived parameter by dividing the PLT by lym. Active inflammatory diseases, active infection, malign conditions, pregnancy, age below 18 years, and use of medications that may interfere with platelet count were set as exclusion criteria.

Commercial SPSS software (SPSS 15.0; IBM Inc., Chicago, IL, USA) was used for statistical analysis. Comparison of homogenously distributed variables in study and control groups was conducted by independent samples t-test and values were expressed as a mean \pm standard deviation. On the other hand, comparison of non-homogenously distributed variables in study and control groups was made by Mann-Whitney U test and variables expressed as median (minimum-maximum). The comparison of categorical variables in study groups was conducted with the Chi-square test. Pearson's correlation analysis was used for the correlation between study parameters. A $p$ value of $<0.05$ was considered as statistically significant.

\section{RESULTS}

A total of 93 individuals, 63 diabetic and 30 control subjects, were enrolled in the study. The mean age of the study and control groups were 56 \pm 9 years and $45 \pm 12$ years, respectively. Diabetic subjects were significantly older than healthy controls $(\mathrm{p}<0.001)$. A total of 33 of 63 diabetic subjects and 21 of 30 healthy controls were women. The sex difference between study and control groups was not statistically significant $(\mathrm{p}=0.11)$.

Although weight was significantly different between study and control groups $(p<0.001)$, height was similar between them ( $p=0.08)$. Both body mass index and waist circumference were significantly higher in the study group compared to the control group ( $p<0.001$ for both). Systolic and diastolic blood pressures were significantly higher in diabetic subjects compared to healthy ones ( $p=0.001$ for SBP and $\mathrm{p}=0.048$ for DBP). General characteristics of the study and control groups were summarized in table 1.

While there was no significant difference between study and control groups in terms of LDL cholesterol $(\mathrm{p}=0.12)$, serum creatinine $(\mathrm{p}=0.06), \mathrm{Hb}(0.92)$ and Htc (0.72) levels, total cholesterol $(p=0.02)$, HDL cholesterol $(p<0.001)$, triglyceride $(p<0.001)$, fasting plasma glucose $(\mathrm{p}<0.001)$, uric acid $(\mathrm{p}<0.001)$, CRP $(p<0.001)$, WBC $(p=0.001)$ and PLT $(p<0.001)$, values were significantly different between diabetic subjects and healthy controls.

Calculated PLR in type 2 diabetic and control groups were 122 (44-472) and 94 (48-170), respectively. The difference between study and control groups was statistically significant ( $\mathrm{p}=0.001)$. The laboratory data of the study and control subjects were summarized in table 2.

PLR was significantly and positively correlated with HbA1c $(\mathrm{p}<0.001, \mathrm{r}=0.58)$, fasting plasma glucose $(\mathrm{p}<0.001, r=0.49)$, and CRP $(\mathrm{p}=0.003, \mathrm{r}=0.30)$ levels in Pearson's correlation analysis test. However, PLR was not correlated with BMI, nor with waist circumference. Figure 1 shows the relationship between HbA1c and PLR.

In the subgroup analysis of 63 diabetic patients, 26 had proteinuria of various levels, and 37 had not. The PLR of type 2 diabetics with proteinuria was significantly higher than that of the diabetic patients without it ( $\mathrm{p}=0.04)$. PLR of diabetic subjects with and without retinopathy was similar $(\mathrm{p}=0.24)$. PLR of diabetic subjects with confirmed diabetic neuropathy 
TABLE 1. GENERAL CHARACTERISTICS OF THE STUDY POPULATION

\begin{tabular}{|c|c|c|c|c|}
\hline & & $\begin{array}{l}\text { Study } \\
\text { Group }\end{array}$ & $\begin{array}{l}\text { Control } \\
\text { Group }\end{array}$ & $\mathrm{p}$ \\
\hline \multirow[t]{2}{*}{ Gender } & Men (n) & 30 & 9 & \multirow[t]{2}{*}{0.11} \\
\hline & Women (n) & 33 & 21 & \\
\hline \multicolumn{5}{|c|}{ Mean \pm standard deviation } \\
\hline \multicolumn{2}{|c|}{ Age (years) } & $56 \pm 9$ & $45 \pm 12$ & $<0.001$ \\
\hline \multicolumn{2}{|c|}{ Height $(\mathrm{m})$} & $1.62 \pm 0.9$ & $1.66 \pm 0.8$ & 0.08 \\
\hline \multicolumn{2}{|c|}{ Weight (kg) } & $82 \pm 13$ & $70 \pm 8$ & $<0.001$ \\
\hline \multicolumn{2}{|c|}{ Body mass index $\left(\mathrm{kg} / \mathrm{m}^{2}\right)$} & $31.4 \pm 5.4$ & $25.6 \pm 4.2$ & $<0.001$ \\
\hline \multicolumn{2}{|c|}{ Waist circumference $(\mathrm{cm})$} & $106 \pm 12$ & $89 \pm 10$ & $<0.001$ \\
\hline \multicolumn{5}{|c|}{ Median (min-max) } \\
\hline \multicolumn{2}{|c|}{$\begin{array}{l}\text { Systolic blood pressure } \\
(\mathrm{mmHg})\end{array}$} & $\begin{array}{l}120 \\
(90-180)\end{array}$ & $\begin{array}{l}110 \\
(100-130)\end{array}$ & 0.001 \\
\hline \multicolumn{2}{|c|}{$\begin{array}{l}\text { Diastolic blood pressure } \\
(\mathrm{mmHg})\end{array}$} & $\begin{array}{l}80 \\
(50-110)\end{array}$ & $\begin{array}{l}70 \\
(50-80)\end{array}$ & 0.04 \\
\hline
\end{tabular}

TABLE 2. LABORATORY DATA OF THE STUDY POPULATION

\begin{tabular}{|c|c|c|c|}
\hline & Study group & Control group & $\mathrm{p}$ \\
\hline \multicolumn{4}{|c|}{ Median (min-max) } \\
\hline $\begin{array}{l}\text { Fasting plasma } \\
\text { glucose (mg/dl) }\end{array}$ & $162(86-565)$ & $95(79-107)$ & $<0.001$ \\
\hline $\begin{array}{l}\text { Serum creatinine } \\
(\mathrm{mg} / \mathrm{dl})\end{array}$ & $0.82(0.63-1.5)$ & $\begin{array}{l}0.75(0.56- \\
1.05)\end{array}$ & 0.06 \\
\hline Uric acid (mg/dl) & $5.6(3.2-8.6)$ & $4.5(2.1-10.4)$ & $<0.001$ \\
\hline CRP $(\mathrm{U} / \mathrm{I})$ & $5(0.1-45)$ & $2.2(0.1-11.9)$ & $<0.001$ \\
\hline $\begin{array}{l}\text { Total cholesterol } \\
(\mathrm{mg} / \mathrm{dl})\end{array}$ & $204(94-325)$ & $168(114-248)$ & 0.02 \\
\hline $\begin{array}{l}\text { LDL- cholesterol } \\
(\mathrm{mg} / \mathrm{dl})\end{array}$ & $123(42-244)$ & $111(53-162)$ & 0.12 \\
\hline $\begin{array}{l}\text { HDL-cholesterol } \\
(\mathrm{mg} / \mathrm{dl})\end{array}$ & $45(25-86)$ & $55(39-77)$ & $<0.001$ \\
\hline Triglyceride (mg/dl) & $166(72-1050)$ & $106(52-297)$ & $<0.001$ \\
\hline WBC $\left(\mathrm{u} / \mathrm{mm}^{3}\right)$ & $7.5(4.4-13.7)$ & $6.3(3.4-9.7)$ & 0.001 \\
\hline $\operatorname{PLT}\left(\mathrm{u} / \mathrm{mm}^{3}\right)$ & $245(141-482)$ & $208(148-263)$ & $<0.001$ \\
\hline PLR & $122(44-472)$ & $94(48-170)$ & 0.001 \\
\hline \multicolumn{4}{|c|}{ Mean \pm Standard Deviation } \\
\hline $\mathrm{Hb}(\mathrm{g} / \mathrm{dl})$ & $13.6 \pm 1.6$ & $13.6 \pm 1.9$ & 0.92 \\
\hline $\mathrm{Htc}(\%)$ & $40 \pm 4.6$ & $40.3 \pm 2.2$ & 0.72 \\
\hline
\end{tabular}

was not significantly different from that of diabetics without diabetic neuropathy $(\mathrm{p}=0.29)$.

\section{DISCUSSION}

The present study showed that PLR was significantly higher in type 2 diabetic patients compared to healthy subjects. Another interesting finding was the positive correlation between HbA1c and PLR in diabetic subjects.

Elevated PLR in patients with type 2 diabetes mellitus may be a reflection of the underlying inflamma- tory burden of the disease. As HbA1c worsens due to poor diabetes control, underlying chronic low-grade inflammatory status intensifies and thus, inflammatory markers, including PLR, increase.

Pathogenesis of type 2 diabetes mellitus is an inflammatory process. ${ }^{5}$ There are many studies in the literature that point to an association between diabetes mellitus and inflammation. For example, Pradhan et al. ${ }^{6}$ suggested that an increase in inflammatory markers such as CRP and interleukin-6 may predict the development of diabetes mellitus. In another study, authors concluded that chronic inflammation in type $2 \mathrm{DM}$ was associated with mortality risk. ${ }^{7}$ Chronic complications from diabetes, in particular, have been linked to the inflammatory status of the patients. ${ }^{8,9}$ Navarro et al. ${ }^{10}$ showed that albuminuria was closely associated with inflammatory markers, including high sensitive CRP and tumor necrosis factor- alpha. Similarly, we found that PLR was higher in diabetic patients with proteinuria compared to those without it. However, this report did not show such a relation in diabetic neuropathy and retinopathy, which may be due to the small study population. Therefore, as an inflammatory index, one can expect increased PLR in diabetic subjects.

PLR has been studied in several clinical conditions as a marker of inflammation. Akboga et al. ${ }^{11}$ studied PLR in coronary artery disease and concluded that it was cheap and easy to assess inflammatory marker, which was helpful in predicting the severity of coronary artery disease. Moreover, PLR has been suggested as an inflammatory indicator in psoriasis, ${ }^{12}$ and rheumatoid arthritis. ${ }^{13}$ Beside diseases with a high inflammatory burden, PLR has also been found to be associated with low-grade inflammatory states, such as cancers. Authors claimed that high PLR has predicted poor prognosis in patients with breast cancer. ${ }^{14}$ Kokcu et al. ${ }^{15}$ reported that PLR was positively correlated with the stage of ovarian cancer. Furthermore, the prognosis of epithelial ovarian cancer could be predicted by an increase in PLR. ${ }^{16}$ These data in the literature suggest that PLR is a strong inflammatory index and type $2 \mathrm{DM}$, as a low-grade inflammatory condition may be associated with elevated PLR.

The inflammatory burden of type 2 diabetes mellitus might be aggravated by poor diabetes control. The positive correlation between PLR and HbA1c reported in the present study suggests this. 


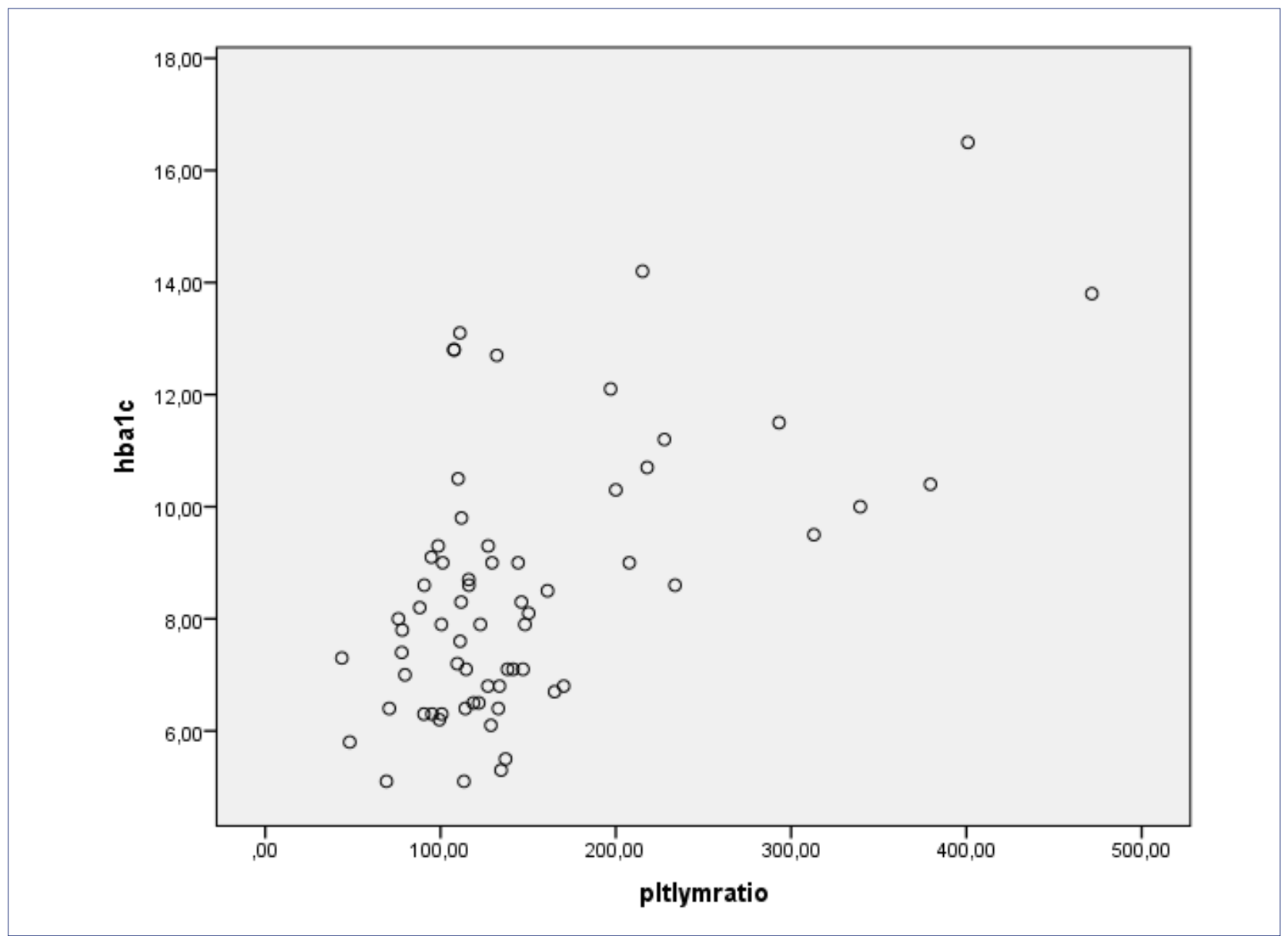

The reason for increased PLR in type 2 diabetes mellitus should be explained by an increased platelet count in diabetic patients. ${ }^{17}$ Limitations of the present report are its retrospective design and the relatively small study population. However, to the best of our knowledge, this is the first study that found an association between PLR and type 2 diabetes mellitus.

\section{CONCLUSION}

The PLR is an inexpensive and simple assessment marker, which can be useful in predicting the development and control level of type 2 diabetes mellitus. However, we believe that its correlation with HbA1c needs to be validated by larger prospective studies.

\section{Conflict of Interest}

None

\section{RESUMO}

O controle diabético poderia ser predicado por Platelet para a relação de linfócitos no hemograma

OBJETIVO: A associação entre diabetes mellitus tipo 2 e inflamação está bem estabelecida. Pretendemos estudar a relação plaquetária com linfócitos $(P L R)$, um novo índice inflamatório derivado do hemograma, em pacientes diabéticos e comparar com aqueles em voluntários saudáveis.

MÉTODOS: Foram registrados e analisados dados médicos de diabéticos de tipo 2 que apareceram em clínicas ambulatoriais de medicina geral de nossa instituição entre fevereiro de 2017 e agosto de 2017.

RESULTADOS: A PLR mediana dos pacientes com diabetes tipo 2 foi significativamente maior que a PLR de controles saudáveis $(p=0,001)$. Além disso, a PLR foi correlacionada de forma significativa e positiva com os níveis de glicemia de jejum $(p<0,001, r=0,49)$ e niveis de proteína c-reativa $(p=0,003, r=0,30)$ com HbA1c $(p<0,001, r=0,58)$. Os indivíduos diabéticos de tipo 2 com proteinúria aumentaram significativamente os níveis de $P L R$ do que os indivíduos diabéticos sem proteinúria.

CONCLUSÃo: Como um índice barato e fácil de usar, a PLR pode ser útil para prever o desenvolvimento e controle do nível de diabetes mellitus tipo 2. No entanto, sua correlação com HbA1c precisa ser validada por estudos prospectivos maiores.

PALAVRAS-CHAVE: Diabetes mellitus tipo 2. Inflamação. Hemoglobina A glicada. Contagem de linfócitos. Contagem de plaquetas. 


\section{REFERENCES}

1. Gustavsson CG, Agardh CD. Inflammatory activity increases with haemoglobin A1c in patients with acute coronary syndrome. Scand Cardiovasc ). 2009;43(6):380-5

2. Ayça B, Akin F, Çelik Ö, Yüksel Y, Öztürk D, Tekiner F, et al. Platelet to lymphocyte ratio as a prognostic marker in primary percutaneous coronary intervention. Platelets. 2015;26(7):638-44.

3. Balta $S$, Ozturk $C$. The platelet-lymphocyte ratio: a simple, inexpensive and rapid prognostic marker for cardiovascular events. Platelets. 2015;26(7):680-1.

4. Peng W, Li C, Zhu WJ, Wen TF, Yan LN, Li B, et al. Prognostic value of the platelet to lymphocyte ratio change in liver cancer. J Surg Res. 2015;194(2):464-70.

5. Donath MY, Shoelson SE. Type 2 diabetes as an inflammatory disease. Nat Rev Immunol. 2011;11(2):98-107.

6. Pradhan AD, Manson JE, Rifai N, Buring JE, Ridker PM. C-reactive protein, interleukin 6, and risk of developing type 2 diabetes mellitus. Jama. 2001;286(3):327-34.

7. Stehouwer CD, Gall MA, Twisk JW, Knudsen E, Emeis J), Parving HH. Increased urinary albumin excretion, endothelial dysfunction, and chronic low-grade inflammation in type 2 diabetes: progressive, interrelated, and independently associated with risk of death. Diabetes. 2002;51(4):1157-65.

8. Jialal I, Devaraj S, Venugopal SK. Oxidative stress, inflammation, and diabetic vasculopathies: the role of alpha tocopherol therapy. Free Radic Res. 2002;36(12):1331-6.

9. Pickup JC. Inflammation and activated innate immunity in the pathogenesis of type 2 diabetes. Diabetes Care. 2004;27(3):813-23.

10. Navarro JF, Mora C, Maca M, Garca |. Inflammatory parameters are inde- pendently associated with urinary albumin in type 2 diabetes mellitus. Am J Kidney Dis. 2003;42(1):53-61.

11. Akboga MK, Canpolat U, Yayla C, Ozcan F, Ozeke O, Topaloglu S, et al. Association of platelet to lymphocyte ratio with inflammation and severity of coronary atherosclerosis in patients with stable coronary artery disease. Angiology. 2016;67(1):89-95.

12. Kim DS, Shin D, Lee MS, Kim HJ, Kim DY, Kim SM, et al. Assessments of neutrophil to lymphocyte ratio and platelet to lymphocyte ratio in Korean patients with psoriasis vulgaris and psoriatic arthritis. Dermatol. 2016;43(3):305-10.

13. Fu H, Qin B, Hu Z, Ma N, Yang M, Wei T, et al. Neutrophil-and platelet-to-lymphocyte ratios are correlated with disease activity in rheumatoid arthritis. Clin Lab. 2015;61(3-4):269-73.

14. Krenn-Pilko S, Langsenlehner U, Thurner EM, Stojakovic T, Pichler M, Gerger A, et al. The elevated preoperative platelet-to-lymphocyte ratio predicts poor prognosis in breast cancer patients. $\mathrm{Br} /$ Cancer. 2014;110(10):2524-30.

15. Kokcu A, Kurtoglu E, Celik H, Tosun M, Malatyalioglu E, Ozdemir AZ. May the platelet to lymphocyte ratio be a prognostic factor for epithelial ovarian cancer? Asian Pac J Cancer Prev. 2014;15(22):9781-4.

16. Raungkaewmanee S, Tangjitgamol S, Manusirivithaya S, Srijaipracharoen $\mathrm{S}$, Thavaramara T. Platelet to lymphocyte ratio as a prognostic factor for epithelial ovarian cancer. J Gynecol Oncol. 2012;23(4):265-73.

17. Akinsegun A, Akinola Olusola D, Sarah JO, Olajumoke O, Adewumi A, Majeed $\mathrm{O}$, et al. Mean platelet volume and platelet counts in type 2 diabetes: mellitus on treatment and non-diabetic mellitus controls in Lagos, Nigeria. Pan Afr Med J. 2014;18:42. 